\title{
Impoliteness in English as a Foreign Language Virtual Classroom: The Strategies and Its intentions
}

\author{
Elsah Amaliah*, Ahmad Bukhori Muslim \\ English Language Study Program, Universitas Pendidikan Indonesia \\ *Corresponding author.Email: elsamaliah@upi.edu
}

\begin{abstract}
The adaption of online learning for whole level education all over the world is happening along this year, then each university student has different expression to reveal what they mean in the virtual classroom. However, the interaction in online learning atmosphere is needed, the students might have strategies and intentions in using impoliteness. Therefore, this present research aimed at investigating the experience of university students in using impoliteness strategies and its intentions at the current learning condition: virtual classroom. The qualitative descriptive method is used by distributing a questionnaire for 3 students of 7th semester in undergraduate class of 2020/2021 selected purposively. According to the findings of this research, in virtual classroom, students tend to use impoliteness strategies and have intentions behind that. The result shows that the responses from 3 students, as last year student in university, indicated that they were using impoliteness strategies in virtual classroom which including bald on record impoliteness, positive impoliteness, negative impoliteness, sarcasm and withhold politeness. Moreover, the intention of using impoliteness is either directly or indirectly because it can be triggered by a number reasons in a specific context.
\end{abstract}

Keywords: Impoliteness, intentions, strategies, virtual classroom

\section{INTRODUCTION}

In online language classroom, interaction must be essentially happened in teaching learning activity. The classroom interaction occurs by all the participant such as teacher to student, student to student, and students to teacher. Dagarin (2004) believes that interaction is mainly achieved by two means of resources: language and non-verbal means of expression, so that the participants interact each other to express ideas and feelings through both verbally and nonverbally in both polite and impolite way. However, in not face to face condition or called online learning, the phenomenon of impoliteness might be showed by the students and the teacher either. Since the interaction in such formal activity is supposed to be polite, the impolite language occurred will cause social conflict or disharmony between teacher and students (Maulana, Mahmud \& Salija, 2019). Meanwhile, the impolite expression cannot be avoided by the students in online learning, because there might be multi-interpretation to the teachers do. Thus, this research aimed to investigate the students' strategies and intentions on implementing impoliteness in virtual classroom activity.
Culpeper (1996) presents a model of impoliteness that is basically the counter part of Brown and Levinson's politeness model. Culpeper takes Brown and Levinson's strategies and inverts them to describe impoliteness and their purpose is to attack the hearer's face instead of trying to save them. Thus, Culpeper analyses impoliteness as consisting of bald on record impoliteness, positive impoliteness, negative impoliteness, sarcasm or mock politeness and withhold politeness. In addition, recognizing intentions of impoliteness is highly problematic as they have to be inferred in communication (Culpeper, 2005). Thus, what has been viewed as the intentions of attacking others' face is the perception of intention that could be rather hypothetical.

Several studies have been conducted by researchers. Culpeper (1996) has studied impoliteness in army recruit training. Culpeper has examined latent impolite intentions of non-commissioned officers (NCOs) towards a female army recruit. Culpeper has reported that the NCOs deploy impoliteness by attacking the recruit's capability, self-worth, and mental sanity. Face attacks are also observed based on the abusive language directed toward the recruit's social role as an American citizen, a soldier, and a potential mother. Non-verbal cues of the 
NCOs such as their sitting positions and the distance of speaking also prompt impoliteness. Tajeddin, Alemi, and Razzaghi (2014) had been investigating native English speakers and English as a Foreign Language (EFL) learners, the researchers discuss the perception brings out by those 2 groups of participants. It is drawn that EFL learners' impoliteness criteria are similar to native speakers', but the amount of emphasis they put on each criterion is different. It underlies EFL instruction (in learning situation) should be aware of impoliteness criteria perceived by native speakers. Then, Dani (2017) discusses the producing of impolite utterance in classroom. Underlying five types of impoliteness strategy; bald on record impoliteness, positive impoliteness, negative impoliteness, sarcasm or mock politeness, and withhold politeness. It is found that male is frequently producing impolite utterance than female does. Regarding the impoliteness intention, a study carried out by Wijayanto, Hikmat and Prasetyarini (2018) reports that Indonesian learners of English frequently use harsh and explicit complaints. The studies have revealed inappropriate use of complaints by L2 learners. Nevertheless, they have only reported post hoc explanations on the directness levels of the complaints. Wijayanto, Laila, Prasetyarini, and Susiati (2013) also found that impoliteness in the complaints provide the better understanding that impoliteness can be triggered by a number of factors occurring in specific contexts.

To fill the gap, this present research seeks to explore impoliteness used by EFL students in virtual classroom. It particularly observes the intentions and strategies of using impoliteness. From the issue about impoliteness, there are two main research questions: (1) What strategies used by EFL students to express the impoliteness in virtual classroom? (2) What are the intentions of using impoliteness? The result of this research might provide important information for language teachers to avoid engaging in potentially impolite interactions in classroom, especially while it is online teaching and learning activity.

\subsection{Virtual Classroom}

In educational contexts, some e-learning courses are offered fully online without any face-to-face interactions while in some contexts, courses are offered with a blended mode that is the use of both face-to-face and online interactions that are facilitated by educational technologies. Online learning environments can offer learners opportunities for flexibility, interaction and collaboration (Gedera, 2014). Also, with the significant growth of e-learning, teachers and students explore new ways of constructing knowledge and enhancing teaching and learning experiences

Online learning is involving several environments called synchronous form such as video conference, online quiz, online chatroom and asynchronous form such as e-mail and passive discussion through some applications. Thus, Tsai (2009) argues that online learners are challenged by new problems which they may have never encountered before in traditional learning environments; for example, how to handle the feelings of isolation and how to solve online technological problems by themselves. Based on the results of an evaluation by Kemendikbud (as cited in Hamid, Sentryo, \& Hasan, 2020), online learning conducted by lecturers and students runs quite effectively even though changes occur in a relatively short time. There were $33.51 \%$ of students who were able to understand online learning materials; $30.90 \%$ understand the material well; and $5.64 \%$ understand the material very well.

\subsection{Impoliteness Strategies}

Culpeper, Bousfield, and Wichmann (2003) stated that when speakers do impolite acts, they not only intend not to maintain the hearers' face, but they also intentionally select offensive language to attack their face. Culpeper provides the definition for impoliteness as a negative attitude towards specific behaviours occurring in specific contexts. It is sustained by expectations, desires, and/or beliefs about social organization, including, in particular, how one person's or a group's identities are mediated by others in interaction. Situated behaviours are viewed negatively - considered 'impolite' - when they conflict with how one expects them to be, how one wants them to be and/or how one thinks they ought to be. Such behaviours always have or are presumed to have emotional consequences for at least one participant, that is, they cause or are presumed to cause offence. Various factors can exacerbate how offensive an impolite behaviour is taken to be, including for example whether one understands a behaviour to be strongly intentional or not.

The most frequently cited definition of impoliteness is from Culpeper (2005) who states that impoliteness comes about when: (1) The speaker communicates faceattack intentionally, or (2) The hearer perceives and/or constructs behaviour as intentionally face-attacking, or (3) A combination of 1 and 2. Impoliteness strategies regularly occur in specific contexts, and those specific contexts are associated with offense.

\subsection{Impoliteness Intention}

Most of the studies have assumed that the speakers' intentionality to attack others' face is what generates impoliteness. However, the intentionality of attacking the other's face is interpreted on the basis of linguistic, prosodic, and non-linguistic data. In other words, it is not informed directly by the speakers. Although the literature has paid attention to speakers' intentionality in the production of impolite acts, however, little has been discussed about intentions and reasons of employing 
impoliteness. This might be because intentions are discursive and hard to access directly from speakers' mind (Haugh, 2010). In addition, recognizing intentions of impoliteness is highly problematic as they have to be inferred in communication (Culpeper, 2005). Thus, what has been viewed as the intentions of attacking others' face is the perception of intention that could be rather hypothetical. Therefore, more research is needed to ascertain the role of intention in the production and interpretation of impolite or rude behaviour (Culpeper, Bousfield, \& Wichmann, 2003). To the best of the knowledge, Bousfield's study is the first that discusses triggers of impoliteness. Nonetheless, little is known about the intentions and reasons of using impoliteness.

In his second definition, Culpeper (2008) links impoliteness to intentionally and says that impolite behaviour can be intentional, on the contrary of Yan Huang (Mohammed \& Abbas, 2016) who states that if intentions and recognition of intentions are involved, then rudeness rather than impoliteness occurs.

\section{METHOD}

This research was a qualitative research design applied descriptive study approach. As Flick, Kardorff and Steinke (2004) states that one of qualitative research procedure directs the description or construction of a case, especially for online learning in this case. The research investigated the activity involving the students who have conducted online learning along 2020. However, this research is the process of in-depth exploration about impoliteness strategies and its intention commonly used by the students in online learning activity in virtual classroom. The research was conducted at one of Universities in Indonesia. The data were collected on December 28th, 2020. There are three undergraduate students of $7^{\text {th }}$ semester majoring English Education Department participated in this research. The participant of this research was chosen purposively based on some reason; they are being a long-time university student, using virtual classroom, and has a brave to express impoliteness in virtual classroom.

The questionnaire adapted from Culpeper's strategies for using impoliteness was distributed to each participant by answering 7 close-ended questions and 3 open-ended question regarding their experiences in online learning. Then, the data are collected and classified based on the Culpeper's classification of impoliteness strategies. The data were collected through giving a questionnaire to the subject of research, then the result of students' responses was analysed. The finding data were categorized into five kind of classifying for the strategies. There were bald on record impoliteness, positive impoliteness, negative impoliteness, sarcasm and withhold politeness. The intention of using kind of impoliteness is also analysed. Furthermore, it was interpreted with the theory based on the literature review.
The data was finally done interpreted and drawn the conclusion on the result of the research which answering the research question stated.

\section{FINDINGS AND DISCUSSION}

To obtain the data regarding students' impoliteness strategies experience in virtual classroom, an open-ended questionnaire was conducted. The research has obtained 7 set of strategies and 3 set of intention for impoliteness question item. The following discusses the strategies and intentions of using impoliteness conducted by the EFL students.

\subsection{Impoliteness Strategies}

Based on the findings, Figure 1 shows that a student indicated as student 1 mostly used withhold politeness in classroom both to the teacher or friend. In this case, student 1 tend to be silent when she is asked to do difficult task, asked to be quiet, being criticized and her bad score is mentioned. Meanwhile, she also used sarcasm in classroom when she is asked to answer difficult question in front of class and her friends have asked her to do something she does not like. Last, positive impoliteness is used when only she is invited to be chatting whilst the class.

The next student, called student 2, also uses impoliteness strategies. It can be seen in Figure 2 that shows the student 2 is indicated to use more often the withhold politeness than the other strategies as well as student 1 . But in this case, the use of withhold politeness is a little bit less than student 1 , because she is silent when the teacher asks her to do difficult task that is not relevant to the course, her bad score is mentioned, and she is ordered to answer the difficult question.

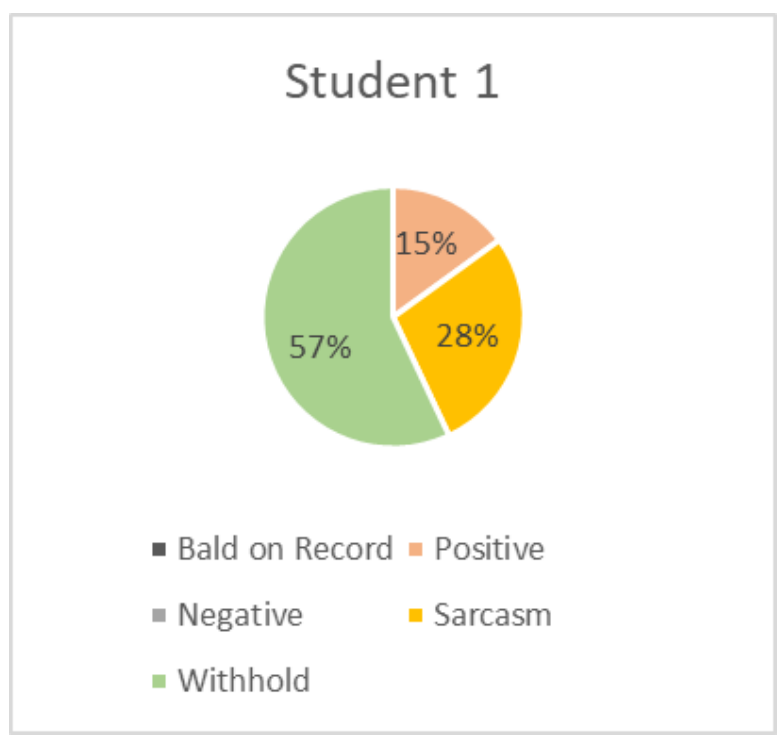

Figure 1 Student 1's impoliteness. 
She will be rejecting or complaining her friends when she is asked to be quiet while her friends is still noisy and when they are asking her to do something she does not really like. it means she uses bald record impoliteness. Then, she will give her positive impoliteness when she is asked to be chatting while class is ongoing. Also, it is used when her bad performance is criticized by anyone.

From the last Figure 3, it can be seen that student 3 does negative impoliteness to the interlocutor. It happens when her bad score is mentioned and asked to answer difficult question in class. Meanwhile, bald on record impoliteness is used when she is asked to do difficult task that is not relevant to the course and her friends ask her to do something she does not really like. In the same quantity with that, sarcasm is used when her bad performance was criticized, and the friends ask her to be quiet in class. She is just being silent when invited to chat over in the class while teaching and learning situation is being conducted.

\section{Student 2}

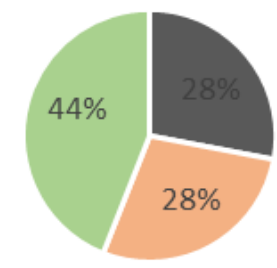

- Bald on Record = Positive

- Negative $\quad$ Sarcasm

- Withhold

Figure 2 Student 2's impoliteness.

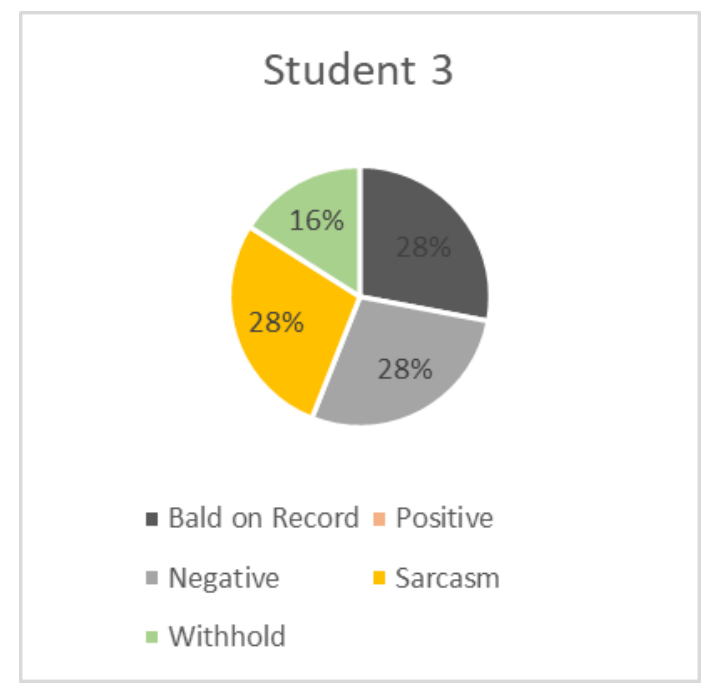

Based on the findings, it can be seen that three students used impoliteness strategies proposed by Culpeper (1996) in virtual classroom context with the teachers or friends. It is indicated that in virtual classroom, both in written or spoken interaction, the five strategies such as bald on record impoliteness, positive impoliteness, negative impoliteness, sarcasm, and withhold politeness appear in classroom conducted by the students. It is important to be highlighted that not all three students conduct all the impoliteness strategies, however at least the withhold politeness was used by all of them. It can be said that they put withhold politeness in the first place of impoliteness strategies, because it is commonly used by students in the virtual classroom interaction.

\subsection{Intention of Using Impoliteness}

The following are several answers by the students who are using impoliteness in virtual classroom when their teacher mentions their bad score in front of the class, their friends ask them to do something they do not really like, and they are being criticized due to their bad performance. Regarding their bad score are mentioned by teacher in front of class, the students assume as follows:

(S1) Because I can't control what people want to do. I choose to be silent, because that the only one thing I can control, how I should respond. My teachers mention my bad score, I can do nothing for that even though I feel disappointed (since I get embarrassed and so on).

In this case, student 1 used withhold politeness. As Culpeper (2005) sates that recognizing intentions of impoliteness is highly problematic as they have to be inferred in communication. It can be seen that rather than to attack the interlocutor face, she tried to control herself to be silent and do nothing to the interlocutor. It is also happened to student 2 who using withhold politeness due to her respect to her teacher even though they are both feel embarrassed.

(S2) Because there is nothing, I can do about it. I am too afraid to do something bad that is related to my teacher.

But, it was different when students 2 assumed:

(S3) I feel like my score is a private thing that teacher can tell me straight instead of telling to the class and I feel like it's embarrassing to hear my bad score so I will probably freak out.

Student 3 were brave to frighten or scorned or use negative impoliteness to the teacher when she felt embarrassed due to her bad score was announced in front of class. She did not want that thing happen, because she thought that it was private thing. It seems that the intention was to attach the teachers' negative face.

Figure 3 Students 3's impoliteness. 
The next presents the intentions of using impoliteness when the friends asked them to do something they do not like much. Students $2 \& 3$ are using bald on record impoliteness. They are straightforward to reject the friends to damage the friends' face. So, it uttered directly for rejecting or complaining. Meanwhile, student 1 used sarcasm because she considered her friends, and she is not kind of a straightforward person.

(S1) Actually I'm that kind of "ga enakan" person who will answer yes whether I like it or not. Even at the end of everything, I clown myself for do so because I say yes without doing it. I lost my value.

(S2) Because I don't want someone to force me to do that, it will be hard for me to do the things that I don't really like. I think it will have the bad impact, whether it for me or for my friends.

(S3) Because I will straight tell my friends what I want or not to do

In dealing with friends who criticized their bad performance, the students assumed:

(S1) Being silent to think, which part I should fix since someone can judge it as bad thing.

(S2) No matter how bad it is; I have tried my best. Everyone has different perspective, if my friends think that it is bad, other people maybe think that it is quite good.

(S3) I appreciate their feedback but deep down I don't want to be criticized and when I'm being criticized, I can't tell the difference whether they hate me or wants me to improve

Student 1 was using withhold politeness, student 2 was using negative impoliteness, and student 3 was using sarcasm. It can be seen that although they use different strategies, the intentions are quite the same; they show their friends that they were not care about the comments, but they are just focus to fix the performances up to make it better. The finding supports Culpeper's (1996) that claim that face attacks can be used to achieve long-term goals such as developing self-discipline.

It is in line with Kienpointner (in Wijayanto, Hikmat \& Prasetyarini, 2018) that has reported that specific emotions can induce impoliteness. This also supports Spencer-Oatey (as cited in Wijayanto, Hikmat \& Prasetyarini, 2018) who has averred that negative emotions can regulate linguistic behaviour. Self-emotion mismanagement which is how not being able to hold back anger can make the speaker be assessed as being impolite. Nonetheless, it should be noted that even though the negative emotions above can trigger impoliteness, they are not the antecedent of impoliteness, but rather the reactions toward offending situations.

\section{CONCLUSION}

To sum up, in virtual classroom or while online learning, the students commonly used impoliteness expression to attack the teachers' or the friends' face. The impoliteness strategies which occurred in virtual classroom consist of five strategies, there are bald on record impoliteness, positive impoliteness, negative impoliteness, sarcasm and withhold politeness. Whereas withhold politeness that showed by being silent was commonly used by three students of $7^{\text {th }}$ in one of universities in Indonesia. It is important to be highlighted that not all three students conduct all the impoliteness strategies, however at least the withhold politeness is used by all of them. It ca be said that they put withhold politeness in the first place of impoliteness strategies, because it is commonly used by students in the virtual classroom interaction.

Furthermore, in using impoliteness, the students have their intentions. Based on the data, it can be inferred that impoliteness is verbal aggression intentionally employed by the students to achieve particular communicative goals, in this case to attack the teachers or friends' face. Moreover, the occurrences of impoliteness either directly or indirectly because it can be triggered by a number of reasons in a specific context.

\section{REFERENCES}

Culpeper, J. (1996). Towards an anatomy of impoliteness. Journal of Pragmatics, 25(3), 349367. https://doi. org/10.1016/0378-2166(95)000143

Culpeper, J. (2005). Impoliteness and entertainment in the television quiz show: The weakest link. Journal of Politeness Research, Language Behaviour, Culture, $\quad 1(1), \quad 35-72 . \quad$ https://doi. org/10.1515/jplr.2005.1.1.35

Culpeper, J. (2008). Reflections on impoliteness, relational work and power. In D. Bousfield, \& M. A. Locher, (Eds.), Impoliteness in language: Studies on its interplay with power in theory and practice (Vol. 21). Berlin: Walter de Gruyter.

Culpeper, J., Bousfield, D., \& Wichmann, A. (2003). Impoliteness revisited: with special reference to dynamic and prosodic aspects. Journal of Pragmatics, 35(10-11), 1545-1579.

Dagarin, M. (2004). Classroom interaction and communication strategies in learning English as a foreign language. ELOPE: English Language Overseas Perspectives and Enquiries, 1(1-2), 127139. 
Dani, E. P. (2017). Impoliteness strategies used by male and female students in classroom interaction. Jurnal Mantik Penusa, 1(2).

Flick, U., Kardorff, E. V., \& Steinke, I. (2004). A Companion to Qualitative Research (J. Bryan, Trans.). London: Sage Publication Ltd.

Gedera, D. S. P. (2014). Students' experiences of learning in a virtual classroom. International Journal of Education and Development using Information and Communication Technology (IJEDICT), 10(4), 93-101.

Hamid, R., Sentryo, I., \& Hasan, S. (2020). Online learning and its problems in the Covid-19 emergency period. Jurnal Prima Edukasia, 8(1), 8695.

Haugh, M. (2010). When is an email really offensive?: Argumentativity and variability in evaluations of impoliteness. Journal of Politeness Research, 6, 731. doi:10.1515/JPLR.2010.002

Maulana, S. S., Mahmud, M., \& Salija, K. (2019) Politeness and impoliteness expressions of students and teacher in English classroom interaction at PPS UNM Sri Sohriani Maulana. Retrieved from https://core.ac.uk/download/pdf/225147699.pdf

Mohammed, H. N., \& Abbas, N. F. (2016). Impoliteness in literary discourse: A pragmatic study. International Journal of Applied Linguistics and English Literature, 5(2), 76-82.

Tajeddin, Z., Alemi, M., \& Razzaghi, S. (2014). Crosscultural perceptions of impoliteness by native English speakers and EFL learners: The case of apology speech act. Journal of Intercultural Communication Research, 43(4), 304-326.

Tsai, M. J. (2009). The model of strategic e-learning: Understanding and evaluating student e-learning from metacognitive perspectives. Journal of Educational Technology \& Society, 12(1), 34-48.

Wijayanto, A., Hikmat, M. H., \& Prasetyarini, A. (2018). Impoliteness in English as a Foreign Language Complaints: Exploring Its Intentions and Motivating Factors. Online Submission, 12(1), 97-104.

Wijayanto, A., Laila, M., Prasetyarini, A., \& Susiati, S. (2013). Politeness in interlanguage pragmatics of complaints by Indonesian learners of English. English Language Teaching, 6(10), 188-201. 